\title{
Development of $\operatorname{IgE}$ and $\operatorname{IgG}$ antibodies to food and inhalant allergens in children at risk of allergic disease
}

\author{
S ROWNTREE, J J COGSWELL, T A E PLATTS-MILLS, AND E B MITCHELL \\ Clinical Research Centre, Northwick Park Hospital, Middlesex and Poole General Hospital, Dorset
}

SUMMARY In a prospective study of 92 children with at least one atopic parent, the development of the specific antibody responses to food and inhalant allergens during the first 5 years of life were assessed. By the radioallergosorbent test egg specific IgE antibody occurred in about $30 \%$ of the children with the mean peak concentration at 12 months. By the second year the prevalence of this antibody had increased whereas the mean concentration had decreased. Milk specific IgE antibody could not be shown in any subject, including four whose skin tests yielded positive results. Food specific IgG antibody was noted by antigen binding radioimmunoassays at 3 months in most children. These responses had peaked and began to fall by the fifth year. In contrast few children had detectable IgE or IgG antibody to inhalant allergens before the first 2 years of life. Both the concentration and prevalence of specific antibody, however, increased from the second to the fifth year and was greater in children whose skin tests yielded positive results.

Breast feeding was associated with an increase in the prevalence of positive results from skin tests but was not associated with detectable IgE antibody to both food proteins, a lower concentration of IgG antibody to cows' milk, and was not associated with protection against the development of disease. A high level of exposure to dust mite was associated with an increased prevalence of positive results from skin tests to dust mite and appreciably higher antibody concentration.

This study indicates differences in the humoral responses to food and inhalant allergens. Environmental factors appear to influence the development of these responses.

In early life infants and young children are exposed to a range of environmental allergens that may stimulate a local or systemic immune response. In subjects with a strong family history of atopy this response often includes the production of $\mathrm{IgE}$ antibody. ${ }^{12}$ Although the common allergic diseases have a hereditary component, quantitative differences in environmental factors may also influence the development of both IgE antibody and disease. ${ }^{2}$ Previously, many studies have focused on the influence of dietary manipulation with some, but not all, suggesting that breast feeding can protect against the development of allergic disease..$^{3-6}$ Less emphasis has been placed on the influence of exposure to inhalant allergens. ${ }^{7}$ Experimental studies in both man and animals suggest that repeated low dose exposure to antigens is more likely to induce a persistent IgE antibody response than high doses of the same antigen. ${ }^{8}$ Thus the differences in quantity, duration, and route of exposure between inhalant and food allergens may influence both the class of the antibody response and the persistence of IgE antibody. It is not known whether the low dose repeated exposure to foreign proteins that may occur during breast feeding renders IgE antibody production more likely. ${ }^{9}$

In this study 92 children with at least one atopic parent were followed up prospectively from birth to 5 years to assess the development of specific antibody responses to food and inhalant antigens.

\section{Patients and methods}

Patients. Ninety two infants were selected for study before birth: their parents had been fully informed of the extent of the study and agreed to participate. 
In all cases at least one parent gave a history of atopic disease. All infants were born in hospital and had a mean birth weight of $3280 \mathrm{~g}$.

Children were examined at birth, 3,6 , and 12 months and thereafter annually to 5 years. At each visit a clinical and environmental history was taken. In addition, parents were asked to keep a daily record of symptoms of the respiratory tract or skin. A careful record of feeding regimen was made, with supervision, to ensure that those infants who were breast fed did not receive cows' milk. A diagnosis of infantile eczema or atopic dermatitis was made when inflammation of the skin was present on the flexural areas or on the face for four weeks or more. The inflammation consisted of papular erythema or lichenification, or both and was associated with pruritus. Transient erythematous lesions or 'cradle cap' were not included in the diagnosis. Wheezing episodes, confirmed on auscultation by one of us (JJC) or the family doctor, were recorded.

Skin tests. Immediate hypersensitivity skin prick tests were performed annually from 1 to 5 years with a battery of six common allergens: Dermatophagoides pteronyssinus, mixed grass pollens, cat fur, dog hair, cows' milk, and hens' eggs (Bencard). Control solutions included histamine $1: 1000$ and diluent alone. A wheal diameter of $3 \mathrm{~mm}$ or greater than that caused by the diluent control solution was regarded as positive. No cases of unresponsiveness to histamine were recorded. Serum samples were also obtained when possible; 72 samples were drawn at 3 months and 48 at 5 years. All procedures were approved by the hospital's ethical committee.

Antigens. Crude protein extracts from hens' eggs, and cows' milk were prepared. Egg white pooled from 5 hens' eggs was diluted $1: 1$ in $0.85 \%$ saline and homogenised. Cows' milk whey was separated from pasteurised whole milk by centrifugation at $12000 \mathrm{~g}\left(4^{\circ} \mathrm{C}\right)$. Purified ovalbumin fraction V (hens' egg) and $\beta$-lacoglobulin (cows' milk) were obtained from Sigma Chemical Company (Poole, Dorset). House dust mite $D$ pteronyssinus antigen $\mathrm{P}_{1}$ was prepared as reported previously. ${ }^{10}$ The major rye grass pollen antigen Rye I was a gift from Dr D Marsh (Johns Hopkins University, Baltimore).

Radioallergosorbent test. Egg, milk, and crude $D$ pteronyssinus antigens were coupled to filter paper discs (Whatman No 541) that had previously been activated with cyanogen bromide. The discs were incubated overnight at room temperature in patients' serum samples, diluted 1:10 in horse serum (in radioallergosorbent assays with milk some serum samples were diluted 1:2.5 in horse serum). After extensive washing in radioallergosorbent test buffer (borate buffered saline, $0.5 \%$ Tween 20 ) the discs were further incubated overnight at room temperature with iodine- 125 labelled anti-IgE, again diluted in horse serum. After extensive washing in radioallergosorbent test buffer the remaining radioactivity was determined by a gamma counter (Nuclear Enterprise NE 1600). The results were compared with the mean binding obtained from five cord serum samples or a standard control serum sample. For house dust mite and milk antigens results were expressed in terms of independent milk and dust mite standard serum samples. A 1:10 dilution of standard serum was arbitrarily defined as 100 radioallergosorbent test units.

Antigen binding radioimmunoassays. Antigen binding assays were used to quantitate specific IgG and IgE antibody. ${ }^{11}$ Antigen (3-7 ng) was radiolabelled and incubated at room temperature with $0.1 \mathrm{ml}$ of a $1: 12.5$ to $1: 100$ dilution of serum diluted in borate buffered saline $\mathrm{pH} 8 \cdot 0$ for three to four hours. Class specific antibody was precipitated overnight $\left(\right.$ at $\left.4^{\circ} \mathrm{C}\right)$ with goat antihuman IgG or IgE. After washing three times in borate buffered saline, residual radioactivity was estimated by a gamma counter. Results for each assay were expressed in arbitrary units of binding activity with reference to doubling dilutions of a standard serum for each antigen. Total IgE antibody concentrations in serum samples were estimated by a double antibody binding radioimmunoassay. ${ }^{12}$

Assay for antigen $\mathbf{P}_{\mathbf{1}}$ on dust extracts. Samples of dust were collected from a number of sites in the homes of 66 patients. A hand held vacuum cleaner (Hoover model No $2614 \mathrm{C}$ ), fitted with a filter holder was used. Samples obtained from $1 \mathrm{M}^{2}$ areas were sieved through an $0.3 \mathrm{~mm}$ mesh screen, extracted with $2 \mathrm{ml}$ borate buffered saline with $0.1 \%$ Tween during two hours of constant rotation, and then centrifuged at $1500 \mathrm{~g}$. The supernatants, having been stored at $-20^{\circ} \mathrm{C}$, were assayed in a double antibody inhibition radioimmunoassay with radiolabelled antigen $P_{1}$ and specifically purified rabbit antihouse dust mite antibody. ${ }^{13} \mathrm{~A}$ control curve was prepared by assaying a standard preparation of purified allergen in parallel with each supernatant. Results were expressed as $n g$ antigen $P_{1}$ in supernatants/g fine dust.

Statistics. The Spearman Rank test was used to correlate food and inhalant specific antibody concentrations and their relation to total IgE. The Mann-Whitney U test was used to compare antibody concentrations in terms of skin test reactivity, 
exposure to house dust mite, and breast feeding. Skin test reactivity and disease were compared with exposure to dust mite and infant feeding regimen by the $\chi^{2}$ test with Yates's correction.

\section{Results}

Food antigens. IgG antibodies to both ovalbumin and $\beta$-lactoglobulin were detected at 3 months in most children, which may partly reflect placental transfer (Fig. 1(a) and (b)). For $\beta$-lactoglobulin the IgG antibody concentration increased from 3 months onwards, reaching $98 \%$ prevalence and high degrees of binding by 6 months, declining slightly by 5 years. In none of these children was IgE antibody to milk proteins detected at any time in the study. A standard control curve giving resolutions to $0.5 \%$ of counts added was used to assay milk specific IgE antibody, and the samples were assayed at higher concentrations-that is $1: 2 \cdot 5$ - to increase the possi- bility of detecting antibodies. For ovalbumin IgG antibody concentrations increased from 6 months to reach a maximum at 3 years and was accompanied in up to $20 \%$ of the children by detectable IgE antibody (Fig. 1(a). There was a decline in the concentrations of both IgG and IgE antibody to ovalbumin between 3 years and 5 years.

Inhalant allergens. Antibodies to antigen $P_{1}$ and Rye I were detected in a small number of serum samples at the end of the first year of life, and the concentrations were low. Over the next four years both prevalence and mean concentration increased steadily (Fig. $1(c)$ and $(d)$. For both allergens the maximum prevalence of IgG antibody was only $40 \%$ and for IgE antibody was $20-25 \%$. There was also an excellent quantitative correlation between IgG and $\mathrm{IgE}$ antibody (antigen $\mathrm{P}_{1}: \mathrm{r}_{\mathrm{s}}=0.698, \mathrm{P}=<0.01$; Rye: $I_{r_{s}}=0.96, P=<0.01$ ), and in no case was IgE antibody detected in the absence of IgG antibody.
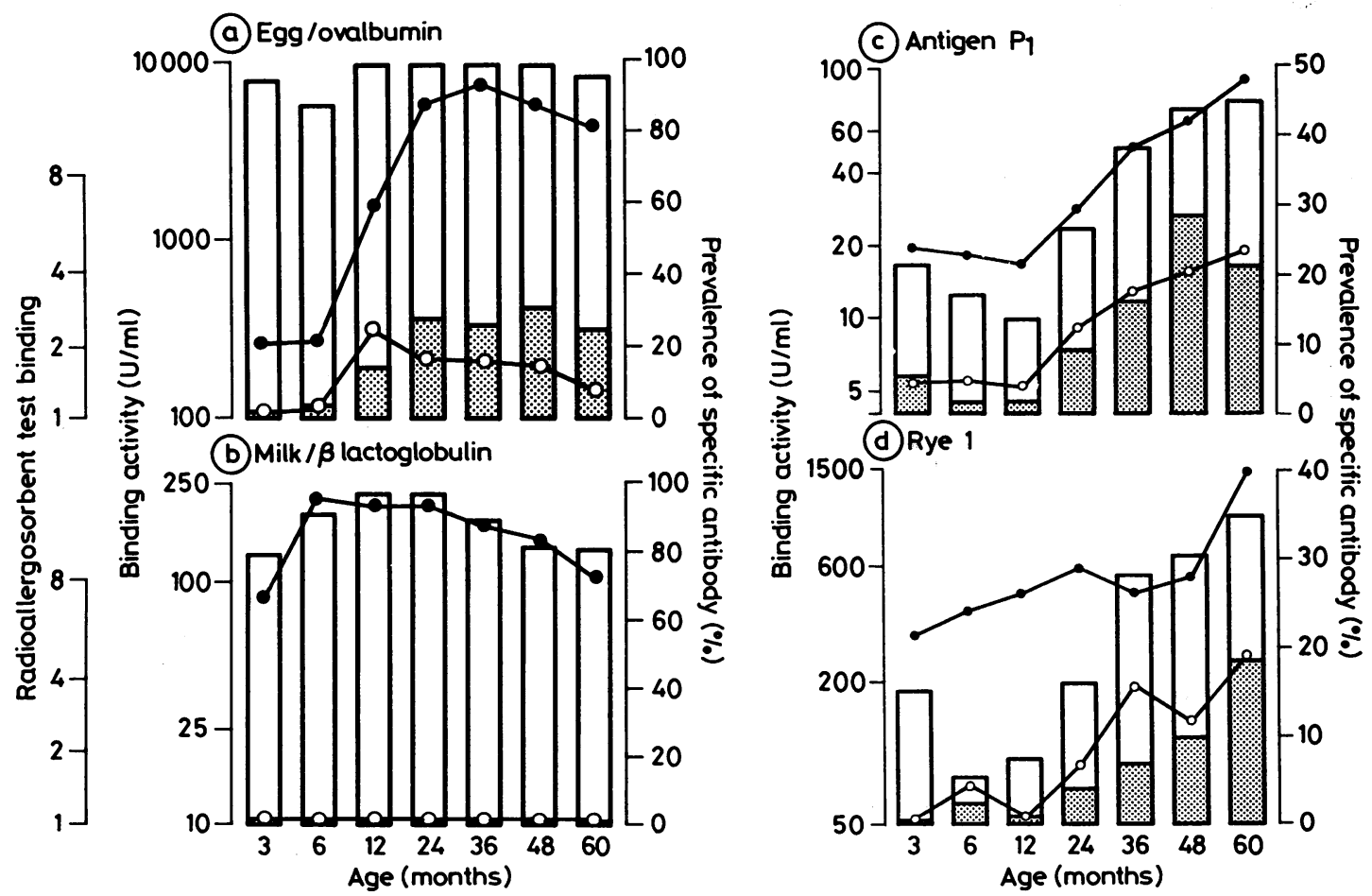

Fig. 1 Specific IgG and IgE antibody to allergens in 92 children studied over a five year period.

Prevalence of IgG specific antibody $=\square$; prevalence of IgE specific antibody=团; geometric mean for IgG antibody positive subjects= -2 : geometric mean for IgE antibody positive subjects $=0-0$. Results for IgG antibody and in the case of Rye $I$ and antigen $P_{1}$ IgE antibody were obtained by antigen binding radioimmunoassay. Individual control curves were produced for each antigen with minimum concentrations of sensitivity as follows: $\alpha$ lactalbumin (10 units/ml). $\beta$-lactoglobulin (10 units/ml), Rye I (50 units $/ \mathrm{ml})$, antigen $P_{1}$ (five units $/ \mathrm{ml}$ ). Results for IgE values to egg and milk proteins were obtained by using radioallergosorbent test. The threshold level for positive binding was defined as one times greater than the mean obtained with five cord scrum samples. Valucs for radioallergosorbent test binding are the ratio of counts bound by the tested serum to the mean for cord scrum samples. 
Furthermore, the mean ratio between $\mathrm{IgG}$ and $\mathrm{IgE}$ antibody (six:one) was comparable to that reported previously in adults. ${ }^{14}$

Correlation between antibodies and results of skin tests. There was a strong positive relation between the presence of positive results from skin tests and specific IgE antibody for both inhalant allergens at 5 years (antigen $\mathrm{P}_{1}: \mathrm{P}=<0.005$; Rye $\mathrm{I}: \mathrm{P}=<0.001$ ). Data for antigen $\mathrm{P}_{1}$ (Fig. 2(a)) also show the correlation between IgG antibody and positive results from skin tests. Most children with positive skin test results and no serum IgE antibody had detectable IgG antibody. The time course showed that $\mathrm{IgG}$ antibody was detectable at the same time as positive results from skin tests and IgE antibody. For ovalbumin the presence of IgE antibody during the first year of life correlated with positive results from skin tests; many infants, however, had positive skin test results with no detectable $\operatorname{IgE}$ antibody (Fig. 2(b)). There was a sharp fall in the prevalence of positive skin test results to egg between the first and second year, from 18 to six $(\mathrm{P}<0 \cdot 01)$. Despite this the prevalence of IgE antibody to egg increased during this period (Fig. 1(a)). Furthermore, children developed IgE antibody without ever showing skin reactivity. In these subjects IgE antibody became apparent about six months later than in subjects

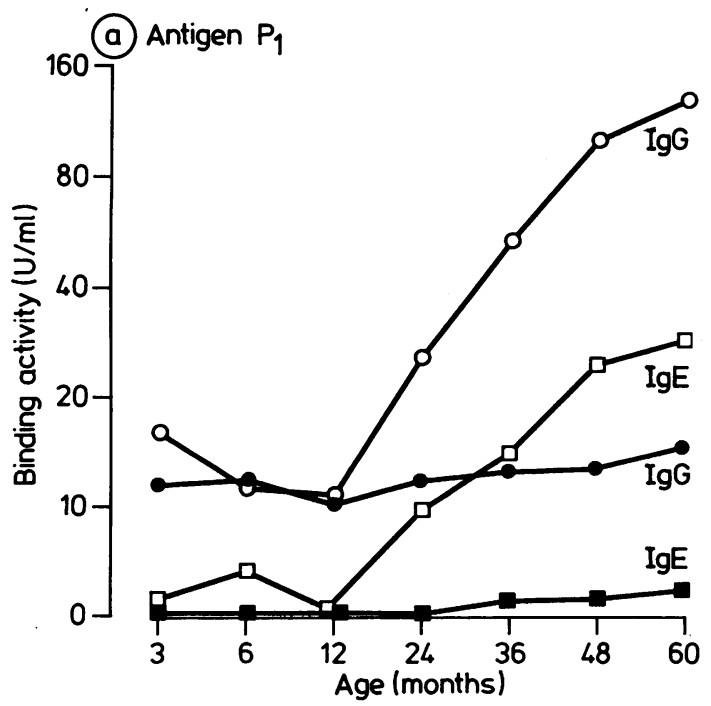

whose skin tests yielded positive results. In the later years, therefore, there were many children who had detectable IgE antibody but negative results from skin tests.

There was no apparent relation between IgE antibody to egg protein and IgG antibody to ovalbumin except that positive results from skin tests and $\operatorname{IgE}$ antibody were not found in the few children who had no detectable IgG antibody. Only four children showed positive skin test results to milk protein, and in each case they had detectable IgG antibody but no detectable IgE antibody.

Relation between serum antibodies and disease. Those subjects who developed positive skin prick test responses or specific IgE antibody during the five year period were more likely to develop diseases than subjects who had no evidence of sensitivity (Table 1). This association was apparent for Rye $I$, antigen $P_{1}$, egg protein, and also in the four patients with positive skin test results to milk protein. Eczema was present at some time in $36 \%$ of the children (Fig. 3). In these children the prevalence of skin test responses to inhalants and egg protein was comparable throughout the five year period. During the first two years, however, the prevalence of eczema appeared to correlate with the presence of egg specific IgE antibody. In later years when the

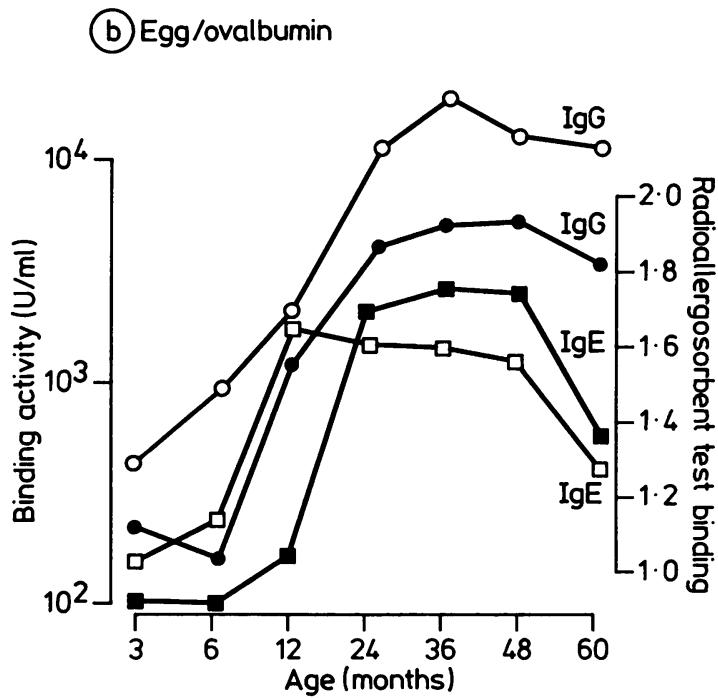

Fig. 2 Relation between specific antibody and skin prick tests.

Geometric mean concentration for IgG: $\mathrm{O}-\mathrm{O}=$ positive skin test result, $-\square=$ negative skin test result and IgE: $\square-\square=$ positive skin test result, - negative skin test result. In (a) subjects with 19 positive skin test results to antigen $P_{1}$ are compared with 64 subjects with negative skin test results. A significant difference in antibody concentrations was apparent $(\mathrm{P}=<0 \cdot 005)$. In $(\mathrm{b}) 17$ subjects with positive skin test results to egg are compared with 20 subjects who were IgE positive and had negative skin test results. No significant difference between concentrations of IgE or IgG antibody was apparent beyond the first year. $(P=>0.05)$ 
Table 1 Prevalence of positive skin test results and specific antibody in disease states*

\begin{tabular}{|c|c|c|c|c|c|c|c|c|c|c|c|}
\hline \multirow[t]{4}{*}{ Allergen } & \multirow{4}{*}{$\begin{array}{l}\text { Age } \\
\text { range } \\
\text { (years) }\end{array}$} & \multicolumn{2}{|c|}{ No disease $(n=16)$} & \multicolumn{6}{|c|}{ Eczema $(n=38)$} & \multicolumn{2}{|c|}{$\begin{array}{l}\text { Recurrent wheezing } \\
\text { only }(n=5)\end{array}$} \\
\hline & & \multirow{3}{*}{$\begin{array}{l}\text { Positive } \\
\text { skin test } \\
(\%)\end{array}$} & \multirow{3}{*}{$\begin{array}{l}\lg E \\
\text { antibody } \\
(\%)\end{array}$} & \multirow{2}{*}{\multicolumn{2}{|c|}{$\begin{array}{l}\text { Definite recurrent } \\
\text { wheezing }(n=17)^{\dagger}\end{array}$}} & \multirow{2}{*}{\multicolumn{2}{|c|}{$\begin{array}{l}\text { Possible recurrent } \\
\text { wheezing }(n=I 1)\end{array}$}} & \multirow{2}{*}{\multicolumn{2}{|c|}{$\begin{array}{l}\text { No wheezing } \\
(n=10)\end{array}$}} & \multirow{3}{*}{$\begin{array}{l}\text { Positive } \\
\text { skin test } \\
(\%)\end{array}$} & \multirow{3}{*}{$\begin{array}{l}\lg E \\
\text { antibody } \\
(\%)\end{array}$} \\
\hline & & & & & & & & & & & \\
\hline & & & & $\begin{array}{l}\text { Positive } \\
\text { skin test } \\
(\%)\end{array}$ & $\begin{array}{l}\operatorname{Ig} E \\
\text { antibody } \\
(\%) \neq\end{array}$ & $\begin{array}{l}\text { Positive } \\
\text { skin test } \\
(\%)\end{array}$ & $\begin{array}{l}\lg E \\
\text { antibody } \\
(\%) \neq\end{array}$ & $\begin{array}{l}\text { Positive } \\
\text { skin test } \\
(\%)\end{array}$ & $\begin{array}{l}\operatorname{Ig} E \\
\text { antibody } \\
(\%) \neq\end{array}$ & & \\
\hline \multirow{2}{*}{ Grass pollen } & $2-3$ & & 9 & 29 & 20 & 9 & 11 & & & 20 & \\
\hline & $4-5$ & 6 & & 47 & 30 & 27 & 18 & & & 40 & 20 \\
\hline \multirow[t]{3}{*}{ Dust mite } & 1 & 7 & 7 & & 6 & & & & & & \\
\hline & $2-3$ & 16 & 20 & 41 & 54 & 9 & 9 & & & & \\
\hline & $4-5$ & 19 & 27 & 41 & 69 & 18 & 10 & 22 & 40 & 20 & 40 \\
\hline \multirow{3}{*}{ Egg white } & 1 & 6 & & 41 & 12 & 18 & 30 & 10 & & & \\
\hline & $2-3$ & & 27 & 18 & 43 & 9 & 66 & 10 & 33 & & \\
\hline & $4-5$ & & 25 & 12 & 37 & & 54 & & 20 & & \\
\hline
\end{tabular}

${ }^{*}$ Children with possible eczema or possible wheeze without definite eczema are not included in this analysis. No child had detectable IgE antibody in milk radioallergosorbent test.

†Four children had positive skin test results to cows ${ }^{\circ}$ milk during the study period. all had eczema with recurrent wheeze.

¥IgE antibody was measured by antigen binding radioimmunoassay (grass pollen Rye $\mathrm{I}$ and dust mite antigen $\mathrm{P}_{1}$ ) and radioallergosorbent test (egg).
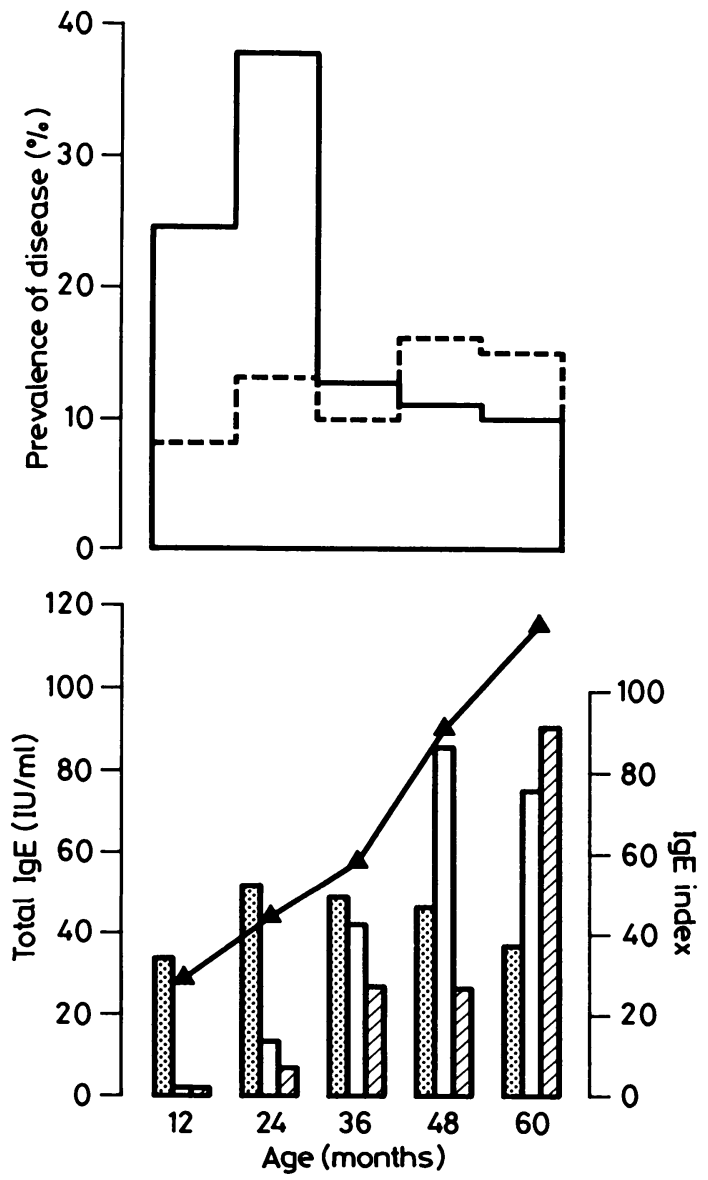

overall incidence of eczema was lower a large proportion of the children who still had symptoms of the skin also had respiratory tract symptoms. In this group, about $10 \%$ of the total at 5 years, the incidence of antibodies to inhalant allergens was high (Table 1, Fig. 3).

Correlation with total serum IgE. The mean concentration of total IgE for the group rose progressively over five years (Fig. 3). The geometric mean concentration at 5 years was greater in those who developed positive results from skin tests (229 $\mathrm{IU} / \mathrm{ml})$ than those with negative results $(73 \mathrm{IU} / \mathrm{ml})$ $(\mathrm{P}<0.002)$. Furthermore, the increase in total IgE antibody from 1 year to 5 years correlated significantly with specific IgE antibody responses to antigen $P_{1} \quad\left(r_{s}=0.975, \quad P<0.001\right)$ and Rye I $\left(r_{s}=0 \cdot 875, P<0 \cdot 001\right)$ but not with $\operatorname{IgE}$ antibody to food allergens (ovalbumin $r_{s}=0 \cdot 003, P>0 \cdot 1$ ).

Relation between amounts of mite allergen in house dust and antibodies to antigen $\mathbf{P}_{1}$. Samples of dust were collected from the homes of 66 patients. Sites

Fig. 3 Specific IgE antibody, total IgE concentration, and disease.

Prevalence of eczema $=-\ldots$ : recurrent wheezing $=-{ }_{-}--$: geometric mean concentration for total $\mathrm{IgE}$ in all subjects $=\mathbf{\Delta}-\mathbf{\Delta}$. Comparison between specific IgE antibody for different antigens is made using an IgE index. The index is calculated as follows: (binding activity in subjects with IgF specific antibody binding activity in negative control subjects) $\times$ prevalence of specific IgE antibody. Egg protein $=$ : antigen $\mathrm{P}_{1}=\square$; and Rye $\mathrm{I}=0$. Total IgF was measured by double antibody inhibition radioimmunoassay and specific IgF antibody was measured by antibody binding radioimmunoassay (antigen $\mathrm{P}_{1}$. Rye I) and radioallergosorbent test (egg protein). 
studied included mattress, bedroom floor, and high level dust from bedroom and living room floors. Individual homes with large amounts of antigen $P_{1}$ in the bedroom carpet had significantly larger amounts in mattresses compared with homes with small amounts in the bedroom carpet $(\mathrm{P}<0.005)$. Bedroom floor dust values were used and the houses regarded as having small amounts $(<2000 \mathrm{ng} / \mathrm{g}$ fine dust), medium amounts $(2-5000 \mathrm{ng} / \mathrm{g}$ fine dust), or large amounts $(>5000 \mathrm{ng} / \mathrm{g}$ fine dust). The prevalence of positive skin test results and IgG antibody to antigen $\mathrm{P}_{1}$ was higher in children exposed to large amounts (Table 2). The concentration of IgE antibody was also higher in these children but just failed to reach significance in both radioallergosorbent and antigen binding assays $(P=0.052)$, unlike IgG antibody $(\mathrm{P}=<0 \cdot 02)$. The incidence of disease was lower in children whose bedroom dust contained smaller amounts of antigen $P_{1}$, but this difference was not significant $(P=>0 \cdot 05)$.

Relation between feeding patterns and immune responses to food and inhalant allergens. As reported previously, the prevalence of allergic disease appeared to be greater in children who were breast fed for greater than 3 months (definite disease $65 \%$, no disease $13 \%$ ) than in those who were bottle fed

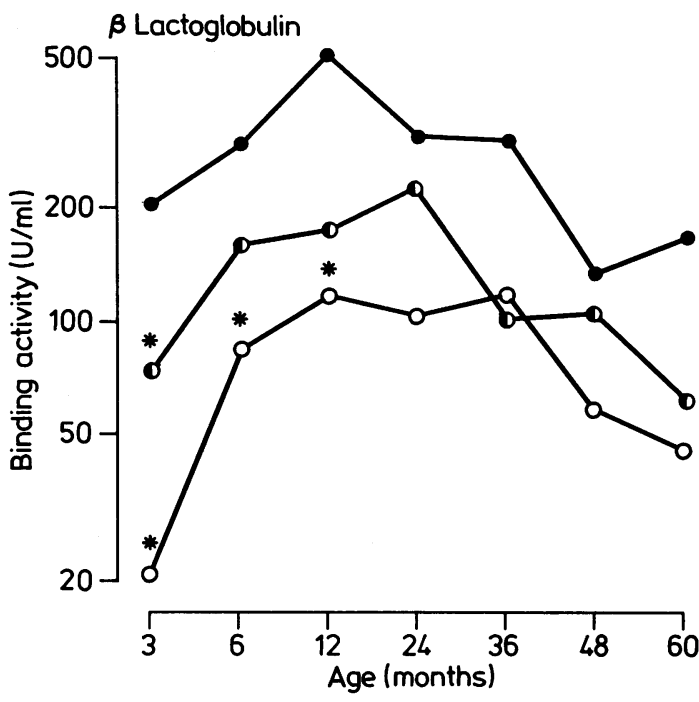

Fig. 4 Infant feeding state and specific IgE antibody concentration to $\beta$-lactoglobulin during 5 years.

Breast feeding $>3$ months $=\mathrm{O}-\mathrm{O} ;<3$ months $=\mathrm{O}-\mathrm{D}$; and bottle feeding from birth $=-0$.

*Significant difference $(\mathrm{P}=<0 \cdot(05)$ between antibody concentrations in those bottle fed from birth and those breast fed (Mann-Whitney $U$ test).

Table 2 Exposure to house dust mite

\begin{tabular}{|c|c|c|c|c|c|c|c|}
\hline \multirow{3}{*}{$\begin{array}{l}\text { Antigen } P_{I} \text { in } \\
\text { dust } \\
(n g / g)^{*}\end{array}$} & \multirow[t]{3}{*}{ No } & \multirow{3}{*}{$\begin{array}{l}\text { Positive } \\
\text { skin test } \\
(\%)\end{array}$} & \multirow{3}{*}{$\begin{array}{l}\text { Positive } \\
\text { radioallergo- } \\
\text { sorbent test } \\
(\%)\end{array}$} & \multirow{2}{*}{\multicolumn{2}{|c|}{$\begin{array}{l}\text { Mean antibody concentration } \\
\text { (binding activity/ml })^{\dagger}\end{array}$}} & \multicolumn{2}{|c|}{ Disease state (\%) } \\
\hline & & & & & & \multirow{2}{*}{ Definite $\neq$} & \multirow{2}{*}{ None } \\
\hline & & & & $\lg G$ & $\operatorname{Ig} E$ & & \\
\hline $\begin{array}{l}<2000 \\
(1062)\end{array}$ & 20 & 15 & 0 & $\begin{array}{l}25 \\
(14-135)\end{array}$ & $\begin{array}{l}7 \\
(5-34)\end{array}$ & 50 & 30 \\
\hline $\begin{array}{l}2-5000 \\
(3542)\end{array}$ & 20 & 40 & 19 & $\begin{array}{l}125 \\
(19-950)\end{array}$ & $\begin{array}{l}28 \\
(5-120)\end{array}$ & 55 & 15 \\
\hline
\end{tabular}

${ }^{*}$ Bedroom floor dust mite (antigen $\mathrm{P}_{1}$ ) concentrations. Geometric means given in parentheses.

tGeometric means and range in parentheses for those subjects showing antibody responses. Results were obtained by antigen binding radioimmunoassay. $\ddagger$ Eczema and recurrent wheezing. Those with possible disease were excluded

Table 3 Prevalence of specific IgE antibody* and positive skin test results $\dagger$ in bottle and breast fed infants. (\% positive results are shown)

\begin{tabular}{|c|c|c|c|c|c|c|}
\hline \multirow[t]{2}{*}{ Allergen } & \multicolumn{2}{|l|}{$\begin{array}{l}\text { Bottle fed }(n=13) \\
\% \text { positive }\end{array}$} & \multicolumn{2}{|c|}{$\begin{array}{l}\text { Breast fed }<3 \text { months }(n=44) \\
\% \text { positive }\end{array}$} & \multicolumn{2}{|c|}{$\begin{array}{l}\text { Breast fed }>3 \text { months }(n=23) \\
\% \text { positive }\end{array}$} \\
\hline & Positive skin tests & $\operatorname{IgE}$ antibody & Positive skin tests & $\operatorname{Ig} E$ antibody & Positive skin tests & $\lg E$ antibody \\
\hline Egg white (ovalbumin) & 8 & 46 & 12 & 32 & 30 & 47 \\
\hline Cows' milk ( $\beta$-lactoglobulin) & 0 & 0 & 2 & 0 & 13 & 0 \\
\hline Dust mite (antigen $P_{1}$ ) & 38 & 38 & 28 & 25 & 35 & 39 \\
\hline Grass pollen (Rye 1) & 31 & 8 & 23 & 20 & 26 & 13 \\
\hline
\end{tabular}

*Measured by antigen binding radioimmunoassay (antigen $\mathrm{P}_{1}$ and Rye $\mathrm{I}$ ) and radioallergosorbent test (egg and milk).

†Positive skin tests any time during the 5 years. 
(definite disease $46 \%$, no disease $31 \%$ ). The difference could not be explained by immune responses to inhalant allergens as no significant differences in either development or concentrations of specific antibodies or results of skin tests were apparent (Table 3 and unpublished data). Antibody responses to food antigens were altered by breast feeding state. Specific IgG antibody concentrations to $\beta$ lactoglobulin increased significantly in the bottle fed group (Fig. 4). The response to egg protein was complex; positive results from skin tests to this food were more common in the breast fed group (Table $3)$. Although IgG antibody to egg protein developed earlier in this group it was neither present more often nor in greater amount (data not shown). The egg specific IgG concentration, however, was significantly greater in subjects who had positive results from skin tests, whether breast or bottle fed.

\section{Discussion}

Our results on the development of antibodies to common food proteins agree with results reported previously in that a large percentage of children have high concentrations of IgG antibody at an early age. ${ }^{15}$ In contrast, antibodies to inhalant allergens are rare during the first year of life but increase steadily from the second year onward. The class of antibody response to inhalant allergens that we found also agrees with previous findings in adults. ${ }^{10} 14$ A close quantitative correlation was seen between IgG and IgE antibody and between both classes of antibody and results of skin tests. The serum IgE antibody could be measured by either radioallergosorbent test or antigen binding radioimmunoassay. Our results showed that IgG antibody developed before or at the same time as IgE antibody. This supports the view that the genetic controls of antibody response to inhalant allergens control both $\operatorname{IgG}$ and $\operatorname{IgE}$ antibodies and are not $\operatorname{IgE}$ antibody specific. Furthermore, for both inhalant allergens there was a good correlation between positive skin test results and specific IgE antibody at all ages.

For the two food allergens the correlations between skin tests and serum IgE antibody was poor. This was due to two separate phenomena. Firstly, in the first two years many of the children had positive skin test results but did not have detectable IgE antibody. Secondly, many of the children older than 2 years had detectable IgE antibody and did not show positive skin test results. We reported previously that detectable serum IgE antibody to milk proteins in adults is uncommon, and it was not found in any of this group of children even though four had positive skin test results.

Clearly, the assessment of immediate hypersensi- tivity to food proteins is not simple. The failure to detect IgE antibody to milk proteins may simply indicate that the concentrations of these antibodies in serum are very low. We previously found that in adults with atopic dermatitis IgE antibody to egg protein could be measured by the radioallergosorbent test but was difficult to detect by antigen binding techniques. We speculated that this problem was due to high concentrations of IgG antibody and possibly low affinity of the IgE antibody. The same problems may apply in this study. It appears, however, that in addition there may be separate factors influencing skin test results. In some cases patients changed from having positive skin test results to having negative results despite the development of increasing concentrations of serum IgE antibody. If IgG antibody is responsible for this switch off of skin reactivity the subclass of the IgG antibody may be relevant. In agreement with others, ${ }^{16}$ we have preliminary evidence that the egg specific $\mathrm{IgG}$ antibody includes $\mathrm{IgG}_{4}$ subclass antibody. Other possibilities to explain this loss of skin test reactivity may include a form of mast cell tolerance; experiments in animals have shown that $\mathrm{T}$ cells produce factors that can influence mast cell function. ${ }^{17} 18$ Our results do not support that skin test results or serum IgE antibody measurements alone assess immediate hypersensitivity to egg proteins, and it seems that both are necessary.

As in previous prospective studies on children, we found a progressive increase in total serum $\operatorname{IgE}$ concentration during the 5 years. ${ }^{4}$ Although both egg specific and inhalant specific IgE antibody concentrations increased during this period, our estimates suggest that only IgE antibody to grass pollen and $D$ pteronyssinus makes a significant contribution to the total concentration. The time course of the inhalant IgE antibody responses correlates better with total $\operatorname{IgE}$ antibody than the time course of the egg IgE antibody, which fell between 3 and 5 years. Our results futher support that $\operatorname{IgE}$ antibody to inhalant allergens makes an important contribution to total serum IgE concentrations in allergic patients. ${ }^{14}$

The high incidence of eczema and intermittent wheezing that developed in these children was expected from previous results and as they had at least one allergic parent. ${ }^{19}$ The prevalence of detectable serum IgE antibody in children with eczema and respiratory tract symptoms $(>65 \%)$ supports the view that there is a direct relation between IgE antibody and disease. There were, however, other children who had recurrent wheezing but no signs of allergy, suggesting that some children have recurrent wheezing associated with viral infections and unrelated to allergy. ${ }^{20}$ In addi- 
tion, there were children with eczema without positive results from skin tests. During the five years, however, those children whose eczema persisted, particularly those who also developed respiratory tract symptoms, had an increasingly high incidence of positive skin test results and serum antibodies to inhalant allergens. $U p$ to $85 \%$ of English schoolchildren with asthma are allergic to dust mites. ${ }^{21}$ Similarly, we reported that children with severe eczema show an increasing incidence of dust mite IgE antibody. ${ }^{14}$ By the age of 5 the range of concentrations of $\mathrm{IgG}$ and $\mathrm{IgE}$ antibody to the inhalant allergens, antigen $P_{1}$ and Rye $I$, were comparable to those seen in adult allergic subjects. The continuing increase in the incidence of bronchial asthma at 5 years would suggest that other factors in addition to the development of a humoral response to these antigens are necessary for disease expression.

There was a correlation between positive skin test results to egg and eczema during the first year, but generally these children did not have detectable serum IgE antibody. Almost all the children developed IgG antibody, and no quantitative difference was apparent between children with or without eczema. In the older children-that is, 3-5 yearsthe relation between $\mathrm{IgE}$ antibody and eczema was increasingly present in keeping with the high incidence of $\mathrm{IgE}$ antibody in serum from children and adults with severe eczema. In conclusion, we do not understand how food antigens contribute to disease in infants, and it is therefore difficult to know whether these are causally important. ${ }^{22}$ Food allergens could contribute to eczema by several different mechanisms including IgG antibody and T cells as well as IgE antibody. In addition, the effect of foods must be altered by the poorly understood factors that influence gastrointestinal absorption. It is not surprising therefore that the relation between eczema and positive skin test results to food antigens was not good.

In this study we observed the effects of two different environmental influences-that is, breast feeding and the amount of mite allergen in the bedroom. Breast feeding for longer than the first 3 months delayed the production of IgG antibody to $\beta$-lactoglobulin but had little effect on development of antibodies to ovalbumin. For both egg and milk protein positive results from skin tests were more common in breast fed infants. Presumably these children are exposed, and the most probable explanation is that they are exposed to small quantities of food protein through their mothers' milk. ${ }^{23} 24$ The implication is that these small quantities of food antigens are more likely to induce positive results from skin tests. When breast fed or bottle fed children were compared after the first year, however, there was no obvious difference either in results of skin tests or concentrations of serum antibodies to food or inhalant allergens. Our results imply that for breast feeding to be successful as a form of avoidance of allergens the quantities of cows' milk and egg protein in the mother's diet would have to be controlled and that breast feeding for the first 3 months would probably not alter the antibody response to inhalant allergens at 2-5 years. Assessment of exposure to dust mite allergen in these children was based on one occasion only, and there may have been major variations during the five years. Nonetheless, a significant correlation was found between the amount of mite allergen and concentration of serum antibodies. This implies that the differences that commonly occur between houses within a single town may be important in influencing the antibody response to mite allergens.

The results of this prospective study of young children has clarified several issues on the development of immune responses to common environmental proteins. Our results for egg proteins showed a complex pattern and evidence that skin test responses are not closely related to the quantity of serum IgE antibody. Nonetheless, the presence of $\mathrm{IgE}$ antibody was correlated with persistent eczema. The effects of breast feeding were also complicated; in the first year positive results from skin tests to egg and milk proteins were more common in infants who were breast fed. After the first year, however, no effects of breast feeding were apparent on either serum antibodies or disease state. Our results for inhalant allergens confirmed the close association between IgG antibody and IgE antibody and also between IgE antibody and skin test results. The results also suggest that there is a simple relation between the quantity of exposure and production of antibodies. Finally, the correlation between development of antibodies to inhalant allergens and both respiratory symptoms and the persistence of eczema suggests a direct relation between the diseases and the immune response.

This study was supported by grants from the Medical Research Council and the Asthma Research Council.

\section{References}

' Dannaeus A, Johansson SGO, Foucard T, Ohman S. Clinical and immunological aspect of food hypersensitivity in childhood I. Estimation of $\operatorname{IgG}, \operatorname{IgA}$ and $\operatorname{IgE}$ antibodies to food antigens in children with food allergy and atopic dermatitis. Acta Paediatr scand 1977;66:31-7.

2 Wutrich B, Baumann E, Fries RA, Schnyder UW. Total and specific IgE (RAST) in atopic twins. Clin Allergy 1981;11: $147-54$.

${ }^{3}$ Matthew DJ, Norman AP, Taylor B, Turner MW, Soothill JF. Prevention of eczema. Lancet 1977;i:321-4. 
${ }^{4}$ Kjellmann N-IM, Johansson SGD. Soy versus cows' milk in infants with biparental history of atopic disease: development of atopic disease and immunological from birth to 4 years of age. Clin Allergy 1979;9:347-58.

${ }^{5}$ Hide DW, Guyer BM. Clinical manifestations of allergy related to breast and cows' milk feeding. Arch Dis Child 1981;56:172-5.

${ }^{6}$ Saarinen UM, Kajosaari M, Backman A, Siimes MA. Prolonged breast feeding as prophylaxis for atopic disease. Lancet 1979;ii:163-6.

${ }^{7}$ Bjorksten F, Suaniemi I, Koski V. Neonatal birchpollen contact and subsequent allergy to birch pollen. Clin Allergy 1980;10: 585-91.

${ }^{8}$ Jarrett EEE, Stewart DC. Rat IgE production I. Effect of dose of antigen on primary and secondary reaginic antibody responses. Immunology 1974;27:365-81.

${ }^{9}$ Schacks ST, Heiner DC. Allergy to breast milk. In: Brostuff J, Challacombe SJ, eds. Clinics in immunology and allergy Vol 2. 1982:121-36.

10 Chapman MD, Platts-Mills TAE. Purification and characterisation of the major allergen from Dermatophagoides pteronyssinus - Antigen $P_{1}$. J Immunol 1980;125:587-92.

1 Platts-Mills TAE, Snadjr MJ, Ishizaka K, Frankland AM. Measurement of IgE antibody by an antigen binding assay: correlation with PK activity and IgG and IgA antibodies to allergens. J Immunol 1978;120:1201-10.

12 Gleich GJ, Averbeck AK, Swedlund HA. Measurement of IgE in normal and allergic serum by radioimmunoassay. J Lab Clin Med 1971;77:690-8.

13 Tovey ER, Chapman MD, Wells CW, Platts-Mills TAE. The distribution of dust mite allergen in the houses of patients with asthma. Am Rev Respir Dis 1981;124:630-5.

14 Chapman MD, Rowntree S, Mitchell EB, Mc Di Prisco de Fuenmajor, Platts-Mills TAE. Quantitative assessment of IgG and $\operatorname{IgE}$ antibody to inhalant allergens in patients with atopic dermatitis. J Allergy Clin Immunol 1983;72:27-33.

15 Dannaeus A, Johansson SGO, Foucard T. Clinical and immuno- logical aspects of food allergy in childhood II. Development of allergic symptoms and humoral immune responses to food in infants of atopic mothers during the first 24 months of life. Acta Paediatr Scand 1978;67:497-504.

${ }^{16}$ Shakib F, Brown HM, Stanworth DR. Relevance of milk and egg specific $\mathrm{IgG}_{4}$ in atopic eczema. Int Arch Allergy Appl Immunol 1984;75:107-12.

17 Nabel G, Gallis ST, Dvorak AM, Dvorak HF, Cantor H. Inducer $\mathrm{T}$ lymphocytes synthesis a factor that stimulates proliferation of cloned mast cells. Nature 1981;291:332-3.

18 Van Loveren H, Kazuyuki K, Meade R, et al. Characterisation of two different $\mathrm{Ly}-\mathrm{1}^{+} \mathrm{T}$ cell populations that mediate delayedtype hypersensitivity. J Immunol 1984;133:2402-11.

${ }^{19}$ Cogswell JJ, Halliday DF, Alexander JR. Respiratory infections in the first year of life in children at risk of developing atopy. $\mathrm{Br}$ Med J 1982;284:1011-3.

20) Mitchell T, Inglis H, Simpson H. Viral infections in wheezy bronchitis and asthma in children. Arch Dis Child 1976;51: 707-11.

${ }^{21}$ Morrison-Smith J, Disney ME, William JP, Goels ZH. Clinical significance of skin test reactions to mite extracts in children with asthma. Br Med J 1969;ii:723-6.

22 Sampson HA. Role of immediate food hypersensitivity in the pathogenesis of atopic dermatitis. J Allergy Clin Immunol 1984;71:473-80.

${ }^{23}$ Van Asperen PP, Kemp AS, Mellis CM. Immediate food hypersensitivity reaction on first known exposure to food. Arch Dis Child 1983:58:253-6.

${ }^{24}$ Stuart CA, Twiselton R, Nicholas MK, Hide DW. Passage of cows' milk protein in breast milk. Clin Allergy 1984;14:533-6.

Correspondence to Dr E B Mitchell, Clinical Research Centre, Harrow, Middlesex HA1 3UJ.

Received 2 April 1985 